\title{
Biotech's wellspring —a survey of the health of the private sector in 2015
}

\section{Brady Huggett}

\section{The eagerness of non-traditional biotech investors made for another good year for the industry. Will it continue?}

ast year, the pace of life science startup Lformation continued to increase. The latest buoyant figures add to an impressive run of prosperity in the private biotech sector. In nearly every possible metric, the sector has outperformed for two straight years. In 2015, private biotechs raised more money than ever before, demolishing the record set in 2014 . They saw the most series A financing rounds closed in biotech's history. Not only did exits for investors remain robust with a slew of initial public offerings (IPOs), but also merger and acquisitions recycled money back to investors at unprecedented rates.

This has not happened in a vacuum. The US economy was strong compared with the rest of the world in 2015, and investment into new ventures in all sectors boomed-nearly $\$ 60$ billion of venture capital (VC) went into US companies in 2015, according to the MoneyTree Report from PricewaterhouseCoopers (New York) and the National Venture Capital Association (Washington, DC, USA), using data provided by Thomson Reuters (New York). That amount is second highest in the past two decades.

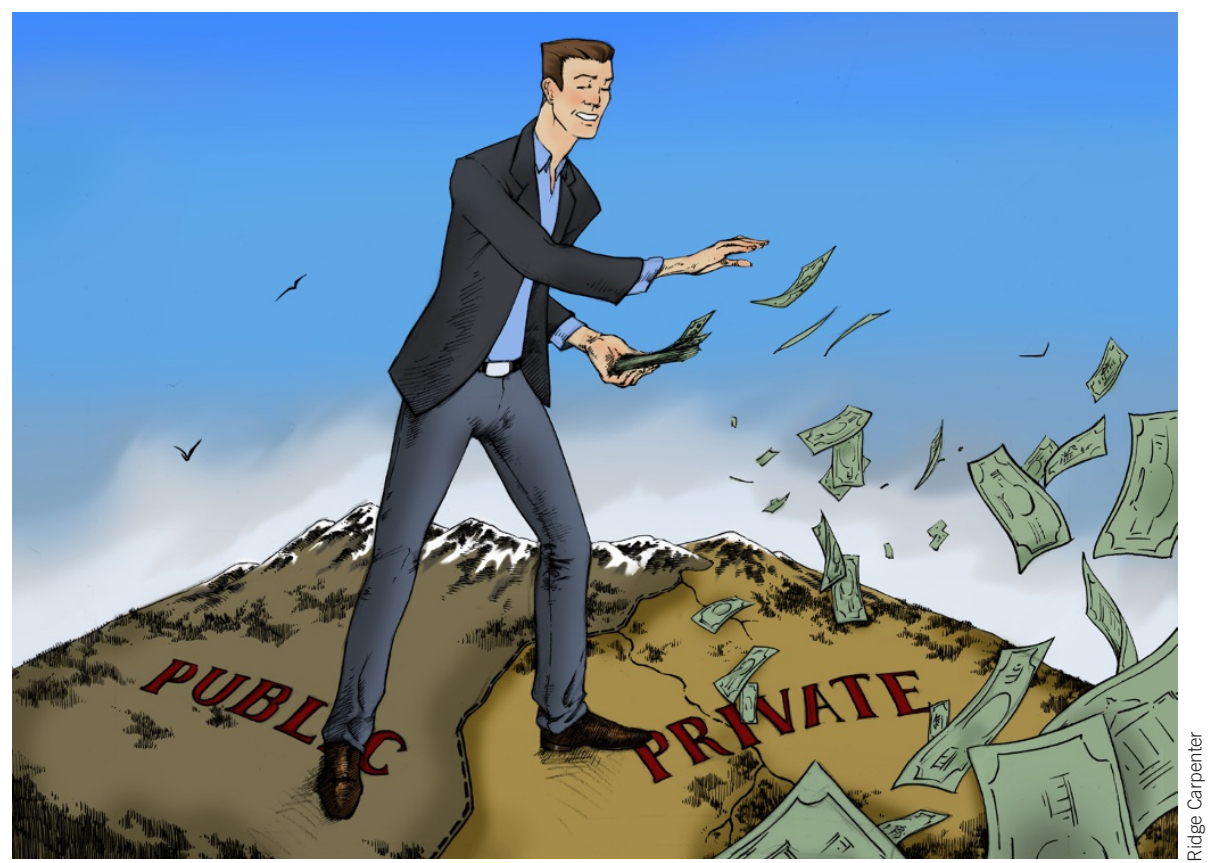

But the amount of investment raised by life science companies was startling, blowing up

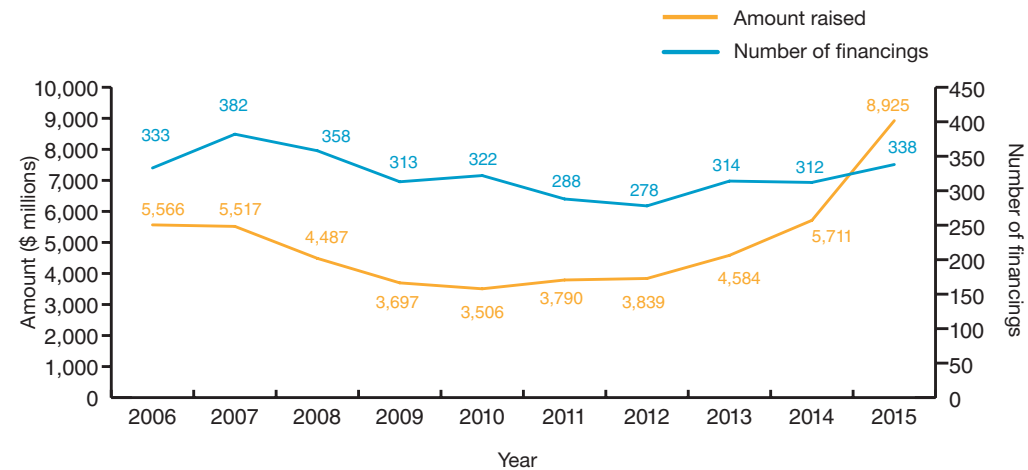

Figure 1 Global amount and number of financings raised through VC funds, 2006-2015. Source: Dow Jones VentureSource. all previous records. Our look at select biotech venture capitalist (VC) activity from Dow Jones VentureSource (Box 1) shows recent peaks for number of rounds, exits and returns, and an all-time high for amount invested. Yet both seasoned biotech execs and newcomers understand the funding bonanza will not last forever. A correction might already be underway-the public markets cooled in the second half of 2015, and then buckled in January. Observers have been beginning to wonder if a reversal is here to stay.

\section{A rising tide}

The sheer number of VC rounds last year for biotech companies (including startups and pre-existing private firms) and the mountainous sums raised have effectively reset the bar for companies seeking equity funding (Fig. 1). The largest round from 2015 is also the largest biotech VC round on record: Moderna 


\section{Box 1 Private biotech defined}

For the purpose of this article, biotech is defined as biomedicine. It does not consider agbiotech, industrial biotech or bioenergy. The dataset encompasses venture-backed drug development firms using technological applications centered on biological systems or living organisms, or their derivatives. Thus, the term 'biotechnology' includes the disciplines of genetics, molecular biology, biochemistry, embryology and cell biology, and can be linked to biomaterials, cell therapy, gene therapy, immunotherapy/vaccines, protein therapeutics, and some specialty pharmaceuticals and small-molecule therapeutics. This definition was partially dictated to us by the dataset provided by Dow Jones VentureSource; when this definition is expanded to consider the wider biotech field, it is noted in the text.

Therapeutics's (Cambridge, MA, USA) $\$ 450$ million (Table 1). This financing is as good a place as any to begin digesting 2015 .

Moderna has raised more than \$1 billion through venture rounds and upfront payments attached to licensing deals. It has at least 50 preclinical programs underway. Moderna's board includes biotech veterans Robert Langer (MIT, Cambridge, MA, USA) and Noubar Afeyan (Flagship Ventures, Cambridge, MA, USA). The technology, which came out of Harvard (Cambridge, MA, USA) focuses on synthetic modified mRNA as therapies. The platform claims to enable the expression of various proteins in vivoantibodies, native or novel proteins and may have unique benefits in delivering pulses of therapy.

At the same time, it remains a young, preclinical company with an untested technology. It has not publicly disclosed a single protein target, any clinical data or recorded product sales. So when Forbes reported in January 2015 that Moderna had a \$3-billion valuation following the latest round, even biotech insiders raised their eyebrows. The record financing became both a beacon for those beginning road shows, and something to point at for those arguing things had gotten out of hand.
CureVac (Tübingen, Germany), another RNA-based company, though focusing more on vaccines, took it as a beacon. Co-founded in 2000 by CEO Ingmar Hoerr, CureVac survived on service contracts, government grants, a tiny equity investment and the largesse of a wealthy individual, Dietmar Hopp, until the Bill and Melinda Gates Foundation (Seattle) approached the company in March 2015 and invested \$52 million (Hopp added another \$24 million). When CureVac then went looking for a sizable venture capital round, it referenced Moderna.

"We'd seen that Moderna was valued at \$3 billion, and we said, [ $\$ 1.4$ billion] is a fair value for us-and we already have clinical data,"

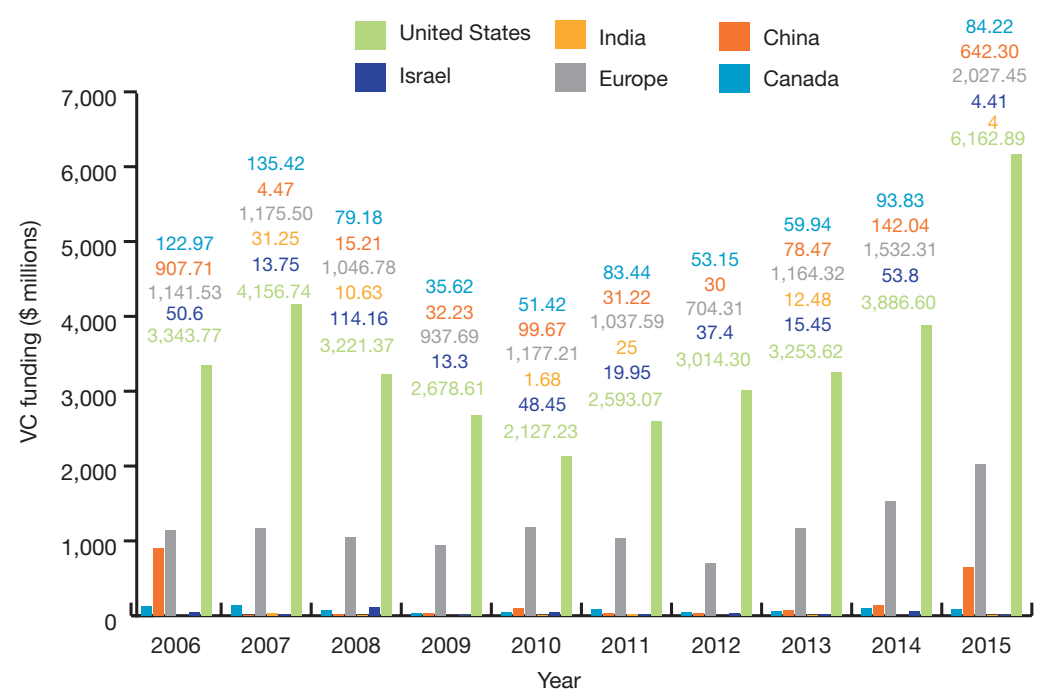

Figure 2 VC investment for drug development biotechs by region. Source: Dow Jones VentureSource.

Table 1 Top VC deals, 2015

\begin{tabular}{|c|c|c|c|c|c|}
\hline Company & Country & Date & Round & $\begin{array}{l}\text { Amount } \\
\text { (\$ millions) }\end{array}$ & Business focus \\
\hline Moderna & US & 5- Jan & 4 & 450 & $\begin{array}{l}\text { Injectable synthetic modified mRNA molecules that produce pulses of protein drugs } \\
\text { when delivered in the body }\end{array}$ \\
\hline Immunocore & UK & 16-July & Later & 320 & $\begin{array}{l}\text { Fusions of monoclonal TCRs and humanized anti-CD3 single-chain variable anti- } \\
\text { body fragments (ImmTACs) for use against cancer, viral infections and autoimmune } \\
\text { disease }\end{array}$ \\
\hline Stemcentrx & US & 31- Aug & 3 & 250 & Antibody-drug conjugates and diagnostics for patients with solid tumors \\
\hline Denali Therapeutics & US & 14-May & 1 & 217 & $\begin{array}{l}\text { Therapeutics targeting disease-causing genes and cellular trafficking defects in } \\
\text { Alzheimer's, Parkinson's and amyotrophic lateral sclerosis }\end{array}$ \\
\hline $\begin{array}{l}\text { Adaptive } \\
\text { Biotechnologies }\end{array}$ & US & 6-May & Later & 195 & Immunoprofiling and diagnostics \\
\hline TauRx & Singapore & 8-Oct & Later & 135 & $\begin{array}{l}\text { Small-molecule Tau aggregation inhibitors for Alzheimer's and fronto-temporal } \\
\text { dementia }\end{array}$ \\
\hline Editas Medicine & US & 4-Aug & 2 & 120 & Therapeutics based on genome-editing technologies, such as CRISPR \\
\hline 23andMe & US & 14-Oct & Later & 115 & Direct-to-consumer DNA diagnostics \\
\hline CureVac & Germany & 29-Oct. & Later & 110 & $\begin{array}{l}\text { Developer of synthetic modified mRNA-based therapeutic and prophylactic vac- } \\
\text { cines }\end{array}$ \\
\hline $\begin{array}{l}\text { Oxford Nanopore } \\
\text { Technologies }\end{array}$ & UK & 21-July & Later & 109.2 & Sequencing \\
\hline
\end{tabular}

Source: Dow Jones VentureSource, BioCentury 
Table 2 Investment by therapeutic modality

\begin{tabular}{|c|c|c|c|c|c|c|c|c|c|c|c|c|}
\hline & \multicolumn{2}{|r|}{2010} & \multicolumn{2}{|c|}{2011} & \multicolumn{2}{|c|}{2012} & \multicolumn{2}{|c|}{2013} & \multicolumn{2}{|c|}{2014} & \multicolumn{2}{|c|}{2015} \\
\hline & No. of deals & $\begin{array}{l}\text { Amount invested } \\
\text { (\$ millions) }\end{array}$ & Deals & Amount & Deals & Afmount & Deals & Amount & Deals & Amount & Deals & Amount \\
\hline Biomaterials & 15 & 112.81 & 17 & 97.23 & 9 & 49.25 & 14 & 138.80 & 10 & 118.16 & 13 & 143.86 \\
\hline Gene therapy & 12 & 101.07 & 21 & 200.03 & 17 & 251.87 & 24 & 317.61 & 33 & 598.80 & 43 & 1451.36 \\
\hline $\begin{array}{l}\text { Immunotherapy/ } \\
\text { vaccines }\end{array}$ & 67 & 783.70 & 46 & 764.61 & 41 & 535.61 & 52 & 889.39 & 57 & 1087.03 & 55 & 1496.49 \\
\hline Small molecule & 58 & 790.74 & 59 & 916.33 & 48 & 707.85 & 73 & 1132.41 & 46 & 813.02 & 55 & 1390.90 \\
\hline Specialty pharma & 18 & 219.2 & 14 & 328.46 & 16 & 150.36 & 14 & 176.38 & 14 & 205.88 & 14 & 199.48 \\
\hline Other & 67 & 729.1 & 59 & 681.96 & 72 & 799.88 & 66 & 1143.09 & 84 & 1518.13 & 80 & 2203.82 \\
\hline
\end{tabular}

Source: Dow Jones VentureSource

Hoerr says. CureVac tapped into the extensive Gates Foundation network and quickly closed a $€ 100$ million (\$110-million) round in October, with Scottish- and US-based investors, and high-net-worth individuals. "I expected a much longer duration for the road show, but it was only two weeks speaking to investors," he says.

The size of the Moderna financing and the speed with which CureVac closed its round exemplified private investing in 2015. Last year, 338 financing rounds went into biotech firms globally (Fig. 1), the highest number in seven years and the most since before the recession fully hit. Those rounds brought in nearly \$9 billion-a 56\% leap over 2014's previous record and almost double the five- and ten-year averages.

The United States itself recorded in 2015 the second highest number of rounds in its history, and a clear record in the amount raised, at $>\$ 6$ billion $-\$ 2.2$ billion more than 2014 (Fig. 2). But activity was also high in China, where companies raised 19 rounds and $\$ 640$ million, and in Canada, with 12 financings for $\$ 84$ million. Europe dipped to 92 rounds, the fewest in 15 years, but the rounds were rich, an increase of almost $\$ 500$ million over 2014.

The opulent rounds in Europe are emblematic of the overall environment. In 2015, the global average amount raised per round was more than $\$ 26$ million (Fig. 3). That is a $44 \%$ increase over 2014, and nearly twice the amount raised per round just three years ago. The leap was driven by companies in the United States, where last year's average of $\sim 29$ million per round is a new peak, besting five- and tenyear averages. Only China raised larger average rounds, at $\$ 33$ million, though they had far fewer. European firms also benefited, averaging $\$ 22$ million per round in 2015, trumping the five-year average of $\$ 13$ million and more than doubling the ten-year average of $\sim \$ 10$ million.

These swollen financings ran all through 2015. The top ten financings in 2014 included five companies that raised more than $\$ 100$ million; in 2015, all ten (Table 1) achieved that level, beginning with Moderna's \$450-million round in January.

Moderna's European financing equivalent was Immunocore (Abingdon, UK), an immunotherapy company developing a platform in which a highaffinity monoclonal T-cell receptor (TCR) is fused to a humanized anti-CD3 single-chain variable anti-

body fragment $(\mathrm{scFv})$ that engages $\mathrm{T}$ cells (termed, ImmTACs, for immune-mobilizing monoclonal TCRs against cancer). Its first product is in phase 2 for malignant melanoma. The company raised $£ 205$ million (\$320 million) in what the company called Europe's largest-ever private financing for a life science company. In addition to its existing investors, Immunocore tapped new ones: Woodford

Investment Management (Oxford), which invests in public and private tech and biotech; Malin (Dublin), an acquirer of biotech companies; and Fidelity Investments (Boston), which traditionally has invested in public equity and fixed-income markets. This is a far cry from a traditional syndicate of venture capitalists, bonding together to scratch up $\$ 30$ million.

\section{Box 2 Fast money}

Axovant Sciences was founded in 2015 and is headquartered in Bermuda, though it has an office in New York, too. The company is owned by parent company Roivant Sciences, founded by Vivek Ramaswamy, a former partner at QVT Financial (New York). Roivant is built to "systemically reduce the time, cost and risk of delivering new drugs to market," and with Axovant, it set out to do just that. Roivant paid $\$ 5$ million (with potential milestone payments) to purchase GSK's intepirdine (RVT-101), a drug the pharma giant had tested in 1,250 Alzheimer's patients in 13 trials before deciding to part ways with it. Setting the drug on course for a phase 3 trial in this notoriously difficult indication, Axovant in June 2015 succeeded in raising $\$ 362$ million in its IPO at a share price of $\$ 15$. The stock nearly doubled on its first day of trading. Many pointed to the quick nature of Axovant's progress - the purchase of an asset discarded by previous developer to highflying IPO in just six months-as the sign that biotech investing sat atop a bubble.

In February 2016, Pfizer revealed it had stopped a trial of a similar Alzheimer's drug for futility, and Axovant's stock took a hit, slipping beneath $\$ 10$ per share before climbing again. 


\section{Box 3 Never a better time}

Long-time biotech builder Index Ventures-a group that split investment between tech and biotech-decided in February 2016 that it was time to physically split its fund, too. The life science team announced the formation of Medicxi Ventures and set up offices in St. Helier (Jersey, UK) and Switzerland, retaining all portfolio life science companies and closing a new €210-million (\$250-million) fund. The team continues to work with Index on prior funds and portfolio companies, but operates on its own with its new fund and going forward.

The move, says partner Francesco De Rubertis, was meant to "double down" on biotech, and the reason for doing so is threefold. The first concerns the FDA: the breakthrough designation given to drugs in development, established in 2012, shows the FDA feels "an urgency" toward approvals for innovative drugs meeting unmet medical needs, De Rubertis says. Since the designation was enacted in 2012, the FDA has granted it to 129 therapies.

The second change is the link between corporate and traditional VCs. The two groups are working together more than ever, and that is giving "increased connectivity" to big pharma, De Rubertis says, no matter where VCs are investing-whether that's at big-name institutions like Harvard or the University of Cambridge, or smaller schools further afield. The more these groups are intertwined, the easier it is for a VC to get an exit through pharma buyout.

The third has to do with pharma. "Twenty, or even ten years ago, pharma was still hoping to do all things itself, from the ground up," De Rubertis says. "But with the restructuring of pharma companies over the past five to ten years, where the early-stage departments have been reduced, pharma is geared to buy their research."

All this adds up to a VC's dream.

Another private biotech registering a top round was Stemcentrx (S. San Francisco, CA, USA), which raised $\$ 250$ million in August 2015, after raising $\$ 100$ million earlier that year. The company's investors include Fidelity, Artis Ventures (San Francisco), and Founders Fund (San Francisco). It is worth noting the involvement of Founders Fund, which was formed by Peter Thiel (who also founded PayPal and was an early investor in Facebook) and includes tech companies, such as Airbnb and the music-streaming service Spotify. Among the antibody-drug conjugates Stemcentrx is developing against various cancers, Rova-T (rovalpituzumab tesirine)a humanized anti-delta-like protein 3 (DLL3) monoclonal antibody (SC16) connected by a dipeptide linker to a DNA-damaging pyrrolobenzodiazepine dimer toxin (D6.5)-is expected to complete enrollment in a phase 2 trial for small cell lung cancer (SCLC) by the end of this year. The company has four other products in clinical trials. The US Food and Drug Administration (FDA) has given Rova-T a breakthrough therapy designation, providing expedited review.

In late April, AbbVie announced it would buy Stemcentrx for $\$ 5.8$ billion in cash and stock, with another $\$ 4$ billion tied to clinical and regulatory milestones. Stemcentrx was founded in 2008 and raised $<\$ 475$ million through three rounds of private financing before the $\$ 5.8$-billion buyout. In investing terminology, that's called a home run.

\section{Splitting the pie}

The largest portion of last year's private investment went to immunotherapy and vaccine companies: $\$ 1.5$ billion, a $37 \%$ increase over the previous high, set in 2014 (Table 2). Of that money, $>\$ 1$ billion went to immunotherapy companies located in the United States.
A close second was gene therapy, raising $\$ 1.45$ billion, a $142 \%$ increase over 2014 levels, and far greater than the five-year average of \$564 million, with US companies again pulling in the lion's share. Voyager Therapeutics (Cambridge, MA, USA) is a standout in this area. The company was formed in 2014 by biotech specialist Third Rock Ventures (Boston) with a \$45-million series A round, and raised another $\$ 60$ million in April of last year, with new investors Brookside Capital (Boston) and Partner Fund Management (San Francisco) leading the round. The company has a mix of five clinical and preclinical programs in adenoassociated virus-mediated gene therapy. In November 2015, it completed an \$80.5-million IPO, moving from inception to public entity in fewer than two years.

Protein therapeutics companies raised nearly $\$ 1.2$ billion, an increase of $35 \%$ over the year prior, with European and US companies commanding near-equal portions of that money.

More than a billion also went into smallmolecule therapeutics, but specialty pharmaceutical companies recorded only about \$200 million in financings, less than in 2014 and slightly below the five-year average ( $\$ 212$ million). Though investment in companies focused on biomaterials rose about $22 \%$, it was an increase of just $\$ 25$ million, showing the field generally garners less interest from venture capitalists than biopharmaceuticals.

An overwhelming amount (81\%) of the $\$ 9$ billion raised in 2015 went to companies in the early, unprofitable stages of their growth (Table 3). This is typical-the average amount invested in product development companies over the past five years is around $85 \%$ of the total, for our set of venturebacked, drug development companies.

Companies generating revenue also received more in 2015, with 79 rounds worth $\$ 1.6$ billion, compared with 53 rounds in 2014 worth $\$ 717$ million. Scant VC money went into 'startup' companies-just three by Dow Jones's count-but these firms are traditionally fed by seed or angel investors.

Table 3 VC investment by stage of development

\begin{tabular}{|c|c|c|c|c|c|}
\hline \multirow[b]{2}{*}{ Stage } & \multicolumn{5}{|c|}{ Number of financing rounds (amount raised $\$$ millions) } \\
\hline & 2011 & 2012 & 2013 & 2014 & 2015 \\
\hline Startup & $15(78.89)$ & $15(38.23)$ & $13(59.52)$ & $12(31.24)$ & $3(19.34)$ \\
\hline Product development & $229(3,351.86)$ & $217(3,311.37)$ & $236(3,927.73)$ & $245(4,905.45)$ & $254(7,241.41)$ \\
\hline Generating revenue & $42(320.28)$ & $45(475.74)$ & $64(590.84)$ & $53(717.66)$ & $79(1,636.07)$ \\
\hline Profitable & $2(39.23)$ & $1(13.82)$ & $1(6.19)$ & $2(56.24)$ & $2(28.44)$ \\
\hline Total & $288(3,790.26)$ & $278(3,839.15)$ & $314(4,584.28)$ & $312(5,710.58)$ & $338(8,925.27)$ \\
\hline
\end{tabular}

Source: Dow Jones VentureSource 


\section{Box 4 Fresh blood}

The past few years have seen new entrants into the biotech investing cadre. Some of the most eye-catching include the following (all venture rounds and IPOs are according to CrunchBase):

EcoR1 Capital was formed in 2013 by Oleg Nodelman, known for his 11 years at Biotechnology Value Fund Partners (San Francisco), one of the first biotech-focused hedge funds. EcoR1 has invested in 18 companies, including Editas, one of EcoR1's seven IPOs.

The hedge fund Rocks Springs Capital was founded in 2013 and focuses on life sciences. Through 2015, it participated in 28 venture rounds and secured 14 IPOs, and one acquisition.

Cormorant Asset Management, a hedge fund in Boston established in 2013 by Bihua Chen, who'd previously been at Fidelity Biosciences and Beacon Bioventures, is also focused on healthcare. It has invested in 24 venture deals from April 2015 through March 2016 and has had seven IPO exits.

Likewise, just two VC rounds went into profitable companies in 2015-those entities have an easier time tapping public markets for investment and have less need for VC attention.

What is telling in these data is the combination of rounds, versus money raised. In 2015, there were 254 rounds put into 'product development' companies, with the United States and Europe leading the way. This was the most since 2008 when there were 281 rounds. Yet the value of those 254 rounds, $\$ 7.2$ billion, was easily the most ever, besting 2014's previous high by more than $\$ 2.3$ billion, and 2008's total by $\$ 3.2$ billion. This is the story of private biotech investing today-massive amounts per round, being offered by non-traditional, generalist investors working alongside the traditional VCs. These 'outsiders' have been piling into the space, throwing their weight into larger and larger rounds, driving up valuations and pushing biotechs toward the public markets at an increasing speed.

\section{Back to you}

Nearly $\$ 3$ billion was raised through IPOs last year, by 42 companies (Table 4 ). That is well above the five-year average, but a substantial step down from 2014 , when $\sim \$ 5.2$ billion went to companies debuting on the public markets through 78 IPOs. The top drug development IPOs for 2015 (Table 5) include Axovant (Bermuda), a company quickly built around a failed GlaxoSmithKline 5-hydroxy tryptamine antagonist small-molecule in Alzheimer's (intepirdine/RVT-101; Box 2); natural killer cell therapy developer NantKwest (Culver City, CA, USA), majority controlled by its billionaire CEO, Patrick Soon-Shiong; and Cassiopea (Milan), a spinout of Cosmos Pharmaceuticals (Luxembourg), which is developing antiandrogen small molecules and antibiotics to treat dermatological indications such as acne and alopecia, and antivirals for the treatment of human papillomavirus. But even the more typical venture-backed private biotechs have had short trips to the public markets.
The gene therapy company Spark Therapeutics (Philadelphia) launched in 2013 with a $\$ 50$ million commitment from The Children's Hospital of Philadelphia. It added in May 2014 a handful of crossover investorswhich, generally speaking, invest in both public and private entities-through a $\$ 72.8$-million series B financing. Eight months later, it closed a \$185-million IPO, providing those VC investors with a (theoretical) exit in fewer than two years, and raised another $\$ 94$ million in a follow-on offering in December 2015.

Blueprint Medicines (Cambridge, MA, USA), a cancer genomics company, moved even quicker. It pulled down $\$ 50$ million in a series C financing in November 2014, supported by a host of crossover investors, and fewer than six months after that private round conducted a \$146.6-million IPO. Nearly the same can be said of all the venture-created companies in our list of top IPOs. Indeed, the average time between the crossover round and IPO for those companies was fewer than eight months. Time is money, and in 2015, it didn't take long for crossover investors to make it in bunches.

These receptive public markets influence merger and acquisition activity. There was a slight increase in overall action last year (Table 4), particularly in Europe, where the 16 buyouts of venture-backed, private biotechs was the largest number seen since the recession, and well over the five-year average of ten. The United States, however, dipped from 20 to 15. Yet the impact of the open public market is felt through the collective value of all those global acquisitions: $\$ 8.8$ billion, an increase over the $\$ 8.45$ billion raised in 2014 -record totals, and well above the five-year average of $\$ 6.3$ billion. When private biotechs have the option of going public for exits, company executives can take a

Table 4 Exits from selected regions

\begin{tabular}{|c|c|c|c|c|c|}
\hline Region & 2011 & 2012 & 2013 & 2014 & 2015 \\
\hline \multicolumn{6}{|c|}{ Number of M\&As (amount raised in $\$$ millions) } \\
\hline Canada & $2(312.85)$ & 0 & $2(102.85)$ & 0 & 0 \\
\hline China & NA & NA & NA & NA & NA \\
\hline Europe & $6(332.79)$ & $7(1009.98)$ & $8(1465.94)$ & $12(1280.93)$ & $16(4163.97)$ \\
\hline India & 0 & $1(60.00)$ & 0 & 0 & 0 \\
\hline Israel & 0 & 0 & 0 & 0 & $2(125.00)$ \\
\hline United States & $26(4338.03)$ & $13(2546.94)$ & $18(3950.30)$ & $20(7168.47)$ & $15(4517.40)$ \\
\hline Total & $34(4983.67)$ & $21(3616.92)$ & $28(5519.09)$ & $32(8449.40)$ & $33(8806.37)$ \\
\hline \multicolumn{6}{|c|}{ Number of IPOs (amount raised in \$ millions) } \\
\hline Canada & 0 & 0 & 0 & $2(82.20)$ & 0 \\
\hline China & $1(43.05)$ & 0 & 0 & $2(66.09)$ & 0 \\
\hline Europe & 0 & $3(54.94)$ & $4(149.16)$ & $17(933.98)$ & $18(946.36)$ \\
\hline Israel & $1(13.95)$ & 0 & 0 & $3(128.70)$ & 0 \\
\hline United States & $3(259.00)$ & $7(456.50)$ & $28(2122.52)$ & $54(4059.40)$ & $24(1969.52)$ \\
\hline Total & $5(316)$ & $10(511.44)$ & 32 (2271.68) & 78 (5270.37) & 42 (2915.88) \\
\hline
\end{tabular}

NA, not available. Source: Dow Jones VentureSource 
Table 5 Top drug development biotech IPOs of 2015

\begin{tabular}{lllc} 
Company & Location & Date & Amount (\$ millions) \\
\hline Axovant Sciences & Bermuda & 10-June & 362.25 \\
\hline NantKwest & USA & 28-July & 238.28 \\
Adaptimmune Therapeutics & UK & 6-May & 191.25 \\
\hline Cassiopea & Italy & 1-July & 187.05 \\
\hline Spark Therapeutics & USA & 30-Jan & 185.15 \\
\hline ProNAi Therapeutics & Canada & 15-July & 158.36 \\
Seres Therapeutics & USA & 26-June & 153.81 \\
\hline Blueprint Medicines & USA & 29-April & 146.63 \\
\hline RegenxBio & USA & 16-Sept & 138.60 \\
Global Blood Therapeutics & USA & 11-Aug & 138.00 \\
\hline Source: BioCentury & & &
\end{tabular}

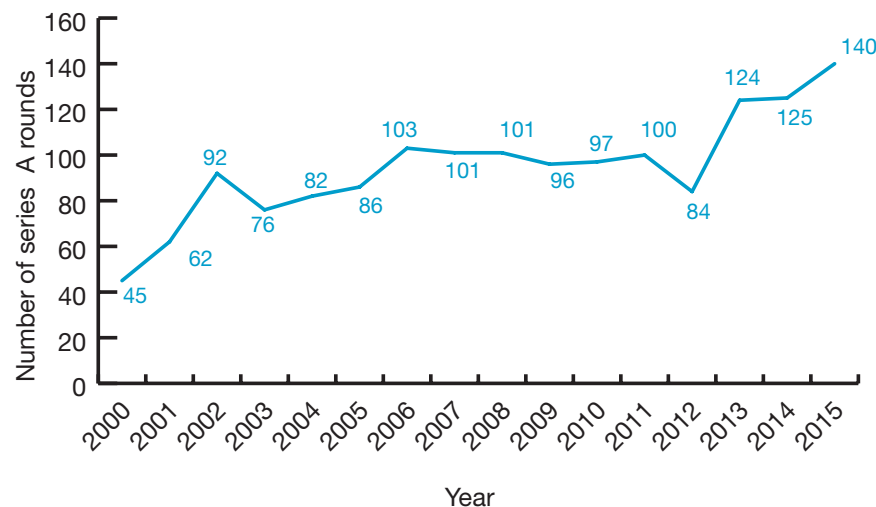

Figure 4 Number of A rounds, 2000-2015. Source: BioCentury. harder stance in acquisition discussions, especially when facing eager pharma companies in need of pipeline filler.

Among last year's buyers was Juno Therapeutics (Seattle), acquiring German biotech Stage Cell Therapeutics, for $€ 52.5$ million (\$59 million), plus stock and potential milestone payments. The move was meant to grow Juno's chimeric antigen receptor $\mathrm{T}$ (CAR T)-cell pipeline, and it gave Juno access to cell selection and activation processes, and manufacturing automation technologies, Juno said. Juno then bought X-Body (Waltham, MA, USA) for \$21 million and stock, plus milestones. Recall that in 2014 Juno raised $\$ 300$ million in two private rounds, and executed its IPO in December for another $\$ 300$ million. That strong financial position has allowed the company to grow by acquisition.

In February, Bristol-Myers Squibb (BMS; New York) bought Flexus Biosciences (San Carlos, CA, USA) for $\$ 800$ million upfront, with another $\$ 450$ million tied to development milestones. The buyout gave BMS several smallmolecule checkpoint inhibitors that target the enzymes indoleamine 2,3, dioxygenase-1 (IDO) and tryptophan 2,3,-dioxygenase (TDO), one of which was cleared in the second half of 2015 for clinical trials. The other programs were spun out into a new entity managed by Flexus's shareholders.

Flexus was founded in 2013; it had raised $\$ 38.4$ million in two quick rounds before the buyout. For those keeping score, and many were, the company went from launch to a potential \$1.25-billion value (including milestone payments) in about 17 months.

That acquisition points to pharma's need for biotech R\&D. Historically, it has gained this through in-licensing or acquisition, as in the Flexus buyout, but in recent years, pharma has begun to interact with biotechs in all sorts of new ways. In January, AstraZeneca, GlaxoSmithKline and Johnson \& Johnson Innovation in London joined up with the technology transfer offices (TTOs) of Imperial College London, University College London and the University of Cambridge to create the Apollo Therapeutics Fund. Each pharma partner is to invest $£ 10$ million over six years, and each TTO is to contribute $£ 3.3$ million. The goal is to fund preclinical academic research until it can be licensed in by one of the pharma partners through a bidding process, and the pharma trio is expected to provide guidance on $\mathrm{R} \& \mathrm{D}$ and commercial aspects of the projects along the way.

Biotech specialist Medicxi Ventures's new $€ 210$-million fund (Box 3) includes participation from GlaxoSmithKline and Johnson \& Johnson Innovation. Indeed, these days pharma is pursuing every avenue into small biotech. Nina Kjellson, general partner at Canaan Partners (Westport, CT, USA), says she sits at the bargaining table with big pharma and "they'll have six or seven people in the room from their side, representing six or seven ways that they can work with venture-backed startups," including members from search and evaluation, from their innovation center, from their M\&A team, or "people investing directly off the balance sheet." It's a long way from the days when pharma licensed a product, or bought the company outright, and that was it.

\section{Crossovers}

When private biotech investment booms, whether in the current or previous cycles, the cause has never been a vastly increased specialist VC base. Though there are new biotech-focused investors being added to the field (Box 4), the deluge of money is coming from outside the regular circle of VCs and pharma corporate investing arms (relatively new to biotech themselves). The private biotech asset class for the past three years has been making money like it's the Bureau of Engraving and Printing, and hedge funds and investor banks would be doing their clients a disservice not to follow the cash flow.
Table 6 Top investors into private biotech of 2015

\begin{tabular}{lccc} 
Investor & $\begin{array}{c}\text { Number of } \\
\text { financings }\end{array}$ & $\begin{array}{c}\text { Total amount raised } \\
\text { (\$ millions) }\end{array}$ & $\begin{array}{c}\text { Average amount raised } \\
\text { (\$ millions) }\end{array}$ \\
\hline OrbiMed Advisors & 26 & 1,149 & 44.2 \\
\hline RA Capital Management & 24 & 1,439 & 60.0 \\
\hline Fidelity & 22 & 1,542 & 70.1 \\
\hline New Enterprise Associates & 21 & 856 & 40.7 \\
\hline Rock Springs Capital & 21 & 1,234 & 58.8 \\
\hline Novartis AG & 18 & 619 & 34.4 \\
\hline Cormorant Asset Management & 17 & 875 & 51.5 \\
\hline SR One & 15 & 521 & 34.7 \\
\hline Polaris Partners & 14 & 443 & 31.7 \\
\hline Sofinnova Ventures & 13 & 542 & 41.7 \\
\hline Jennison Associates & 13 & 858 & 66.0 \\
\hline Versant Ventures & 13 & 460 & 35.4 \\
\hline Novo A/S & 13 & 491 & 37.8 \\
\hline Deerfield Management & 12 & 614 & 51.1 \\
\hline Foresite Capital Management & 12 & 709 & 59.1 \\
\hline Source: BioCentury & & &
\end{tabular}




\begin{tabular}{|c|c|c|c|c|c|c|}
\hline \multirow[t]{2}{*}{ Firm } & \multicolumn{6}{|c|}{ Rounds ${ }^{\mathrm{a} / y e a r}$} \\
\hline & 2011 & 2012 & 2013 & 2014 & 2015 & Q1/2016 \\
\hline RA Capital & 1 & 2 & 4 & 12 & 25 & 0 \\
\hline Rock Springs Capital & 0 & 0 & 1 & 9 & 19 & 0 \\
\hline Deerfield Management & 1 & 1 & 5 & 12 & 12 & 5 \\
\hline Foresite Capital & 0 & 0 & 3 & 5 & 13 & 0 \\
\hline Fidelity Investments & 0 & 1 & 0 & 2 & 20 & 1 \\
\hline Cormorant & 0 & 0 & 0 & 0 & 18 & 6 \\
\hline Jennison Associates & 0 & 1 & 1 & 3 & 13 & 0 \\
\hline Perceptive Advisors & 0 & 0 & 1 & 6 & 10 & 0 \\
\hline EcoR1 Capital & 0 & 0 & 1 & 4 & 11 & 0 \\
\hline Redmile Group & 1 & 1 & 2 & 7 & 8 & 1 \\
\hline Casdin Capital & 0 & 0 & 4 & 2 & 8 & 1 \\
\hline Wellington Management & 0 & 1 & 0 & 6 & 8 & 0 \\
\hline Adage Capital Management & 0 & 1 & 1 & 6 & 4 & 0 \\
\hline Woodford Investment & 0 & 0 & 0 & 4 & 7 & 3 \\
\hline Sabby Capital & 0 & 0 & 0 & 6 & 4 & 0 \\
\hline Total & 3 & 8 & 23 & 84 & 180 & 17 \\
\hline
\end{tabular}

A list of the most active investors of 2015 (Table 6) has OrbiMed (New York) again atop the throne. This is a long-standing investing enterprise that has more than 100 healthcare companies in its private fund portfolio, while managing about $\$ 15$ billion across the public and private spaces. OrbiMed was the top investor in private drug development companies for 2014, too, although last year, it increased its participation to 26 rounds valued at $\$ 1.14$ billion-a nearly $40 \%$ jump in money invested.OrbiMed has also participated in more robust rounds than previously. The average value of the rounds OrbiMed participated in during 2014 was $\$ 37$ million. Last year, the average climbed to $\$ 44$ million.

Below OrbiMed are crossover investors RA Capital (Boston) and Fidelity, both with major increases in volume over 2014: Fidelity leaping from 9 to 22 investments in 2015, and RA Capital moving from 10 to 24 . Fidelity also had the distinction of investing in the most lavish rounds, on average, at more than $\$ 70$ million per investment. Rock Springs
Capital (Baltimore) and Cormorant (Boston) also make the top 10 .

The crossover investors are the force behind the record amounts being crop-dusted over biotech (Table 7). The group in Table 7 invested in just three private biotech rounds in 2011, and eight in 2012, before nearly tripling, then almost quadrupling the number again, and finally reaching 180 investments last year, peaking in the third quarter.

Looking at those piles of money, the first question that rises is, What happens if it all goes away?

\section{Public feeds private}

Ian Sanderson is the former chief financial officer at Catabasis (Cambridge, MA, USA), a company developing an omega-3 fatty acid linker technology to combine different smallmolecule drugs against inflammatory conditions. Before Catabasis, he spent some time working in investment banking. "When I was inside the industry," he says, "what I always underestimated was the power of the general-

\begin{tabular}{lcccccc} 
Table 8 & Number of active VC firms* \\
Region & $\mathbf{2 0 1 0}$ & $\mathbf{2 0 1 1}$ & $\mathbf{2 0 1 2}$ & $\mathbf{2 0 1 3}$ & $\mathbf{2 0 1 4}$ & $\mathbf{2 0 1 5}$ \\
\hline Canada & 10 & 19 & 8 & 10 & 7 & 14 \\
\hline China & 3 & 7 & 3 & 6 & 14 & 18 \\
\hline Europe & 111 & 75 & 80 & 80 & 89 & 78 \\
\hline India & 3 & 1 & & 6 & & 2 \\
Israel & 6 & 6 & 8 & 3 & 5 & 1 \\
\hline USA & 140 & 131 & 151 & 153 & 156 & 153 \\
\hline Global total & 247 & 212 & 214 & 222 & 238 & 229 \\
\hline
\end{tabular}

Source: Dow Jones VentureSource. *The global total is not the sum of all regions, as an investor involved in many regions

counts only once in the global total. 
preclinical Editas a valuation nearing $\$ 1.5$ billion. Observers exhaled.

There were ten biotech IPOs in 2016's first quarter. Slower than last year, but not as dry as some had expected. Yet if that pace continues, it will mean a much lower level of crossover investment for 2016. There have already been signs of a slowdown in private financing. A report from Venture Valuation, which uses data from the database Biotechgate (https:// www.biotechgate.com/web/cms/index.php/ start.html), shows that, after a solid January and February, private biotech (therapeutics and diagnostics) investing fell by nearly $40 \%$ in March from the month prior, with most of that decline coming from the United States. Data also show March recorded 26 financing rounds in 2016, raising \$245 million, versus 41 for $\$ 978$ million in 2015.

\section{What remains}

The number of VC investors (including corporate investment arms) that participated in at least one round in 2015 dipped to 229 in 2014 , down from 238. Most of those VC firms did their work in the United States, participating in 153 rounds, about the same amount as in each of the previous four years (Table 8).

Still, data from biotech multimedia company BioCentury show that 140 series A rounds were closed in 2015-15 more than 2014 and more than any other year in biotech's history (Fig. 4). In the past three years alone, 389 young, small biotechs raised their first rounds and opened for business. Often, even in high times like these, complaints surface that not enough VC money goes to new biotechs, but Figure 4 suggests that over the past three years, this grumbling isn't caused by dwindling supply as much as by increasing demand.

However, the argument can be made that the amount of $\mathrm{VC}$ attention for biotech firms is not increasing fast enough. Data from 2016's National Venture Capital Association Yearbook show that VCs in 2015 put $88 \%$ more money into biotech than a decade earlier, but through only $12 \%$ more deals. Interest in software companies, however-built relatively inexpensively with much shorter product timelines-has exploded. VCs in 2015 put $340 \%$ more money into this sector than in 2005 , through $84 \%$ more deals. Biotech entrepreneurs salivate for that type of growth.

The sense of doom that persisted in the early part of the year, when January passed without a NASDAQ biotech IPO, has abated. Through April, a dozen companies have gone public, and the dropping NASDAQ biotech index has leveled off. It's likely 2016 will reveal biotech inhabiting the other side of a spike, but not a disaster.

That's partially because disaster is harder to come by in biotech than it once was. Rodger Novak, CEO and a co-founder of CRISPR Therapeutics (Cambridge, MA, USA), says that the "blue chip investors are much better educated" than they used to be.

"I think they have an understanding of the risk now," he says. "If something goes south [with one company], I don't think that spills over to other technologies. It might have some impact, but people have a much better understanding of what they are doing."

In other words, even if clinical trial results from a high-flier like Juno or Editas call into question the entire CAR T-cell or CRISPR fields, or if outside forces-2016 is an election year, after all-pull the public markets into tumult, it seems less likely that biotech will enter another desert, like the one seen in 2009.

Ken Horne, CEO of Symic Biomedical, (Emeryville, CA, USA), also has experience as a venture capitalist. "I see a lot of diversification in terms of capital sources now," he says. "Traditionally, it used to be $30 \mathrm{VCs}$ that did life sciences. It went to 50 and then 100 back in 2007, before it contracted down to 30 [in the recession]. Now it's back to 50 . We know those crossover guys are going to go away again, but besides VCs and crossovers, now you've got family offices and you've got [limited partners] and you've got sovereign funds. There is money out there-you just have to work creatively to go find it."

Art Krieg, founder and CEO of Checkmate Pharmaceuticals, (Cambridge, MA, USA) secured \$20 million in a series A in August 2015. He also co-founded Coley Pharmaceutical
(Wellesley, MA, USA) and RaNA Therapeutics (Cambridge, MA, USA), and served as CFO at Sarepta Therapeutics (Cambridge, MA), so he has a long view on biotech's fluctuations. "People are worried about the indices being down, but my god, they've gone up by so much over the last few years," he says. "And the amount of capital that is now in venture capital funds to be deployed for new rounds? Even if the generalists pull out of the sector and there is no new capital coming in for a while, there is enough there to sustain a lot of the existing companies."

Biotech remains one of the few growth industries the United States has, and it has been resurgent in Europe of late. In fact, all over the world, economic development plans increasingly encompass biotech's entrepreneurism. The sector is on solid ground. But perhaps biotech actually needs a downturn. Periods of welcoming public markets and heavy investment from outsiders lead to some bad habits (Box 2), and companies that might otherwise not attract attention are formed and become public. In times like this, metaphorically, the herd grows fat.

Canaan's Kjellson adheres to this theory. "I'm a believer that pressure and adversity distills quality," she says, and points to the "nuclear winter" of 2009-2011, when companies had to be built with responsible business plans, disruptive science and thoughtful financing to attract investors. "I think this current incredible renaissance has been enabled" by those companies being formed, she says.

"And in the background of that," she adds, "we have tenfold as many seasoned experienced entrepreneurs in biotech as we used to, and we've had phenomenally talented people coming out of the best pharma companies due to their [layoffs and reorganizations], as well. They believe they can do better science, and faster, more exciting projects within these venture-backed biotech companies than they could within their much larger, bloated infrastructure in pharma."

After 2015, they have a fresh $\$ 9$ billion with which to do it. 